\title{
PENINGKATAN KOMPETENSI DAN PENGETAHUAN APOTEKER TERHADAP OBAT OFF LABEL MELALUI WORKSHOP AND TRAINING
}

\section{IMPROVEMENT OF APPLICATION COMPETENCE AND KNOWLEDGE ON OFF LABEL MEDICINE THROUGH WORKSHOP AND TRAINING}

\author{
Suharjono \\ Fakultas Kedokteran Hewan \\ Mahardian Rahmadi \\ Fakultas Kedokteran Hewan \\ Chrismawan Ardianto \\ Fakultas Kedokteran Hewan \\ Arina Dery Puspitasari \\ Fakultas Kedokteran Hewan \\ Dewi Wara Shinta \\ Fakultas Kedokteran Hewan
}

\begin{abstract}
ABSTRAK
Informasi obat off label belum banyak diketahui dan dipahami oleh para tenaga kesehatan, baik dokter maupun apoteker. Peresepan obat off label juga akan berdampak pada aturan etik dan biaya obat, apakah legal dan bisakah ditanggung oleh asuransi. Oleh sebab itu, perlu adanya suatu kegiatan pendidikan berkelanjutan kepada para Apoteker dan profesi kesehatan untuk memberikan informasi dan pemahaman peserta dengan perkembangan obat off label. Kegiatan ini bertujuan untuk meningkatkan kompetensi para peserta, juga memahami aturan peresepan yang legal dan sebagai masukan untuk asuransi serta peraturan farmasi. Bentuk kegiatan yang akan dilakukan adalah workshop dan training. Acara dilakukan selama 2 hari, 14-15 Oktober 2018 di Graha Iptekdok, FKUA. Terdapat 10 narasumber dengan 11 materi yang dibagi dalam 6 workshop, dan 1 kegiatan pelatihan Micromedex. Kegiatan ini dihadiri oleh 383 peserta dan 5 undangan. Diantara 383 peserta, 55\% merupakan apoteker yang bekerja di rumah sakit, 30\% adalah apoteker yang bekerja di apotek, dan sisanya adalah apoteker yang bekerja di industri, puskesmas, dinas kesehatan, dan mahasiswa farmasi. Domisili peserta berasal dari berbagai daerah, dengan prosentase terbesar dari Jawa. Berdasarkan hasil evaluasi kuesioner, rata-rata penilaian kesesuaian materi dengan kebutuhan peserta adalah 8 dari skala 10. Selain itu, penguasaan materi oleh narasumber juga sangat baik ( 8 dari skala 10). Sedangkan dari segi acara, rata-rata peserta menilai sangat baik (7-9 dari skala 10). Nilai 7 diberikan pada parameter fasilitas ruangan. Melihat antusiasme dari peserta off Label Drugs Workshop and Training in Community and Clinical Settings, maka panitia berencana akan melakukan tindak lanjut dengan mengadakan acara yang serupa untuk mengakomodir calon peserta yang tidak dapat tertampung pada acara ini.
\end{abstract}

Kata kunci: Off Label Drug, Workshop, Training, Apoteker

\section{ABSTRACT}

Drug information off label is not widely known and understood by health workers, both doctors and pharmacists. Prescribing drugs off label will also have an impact on ethical rules and drug costs, whether legal and can be covered by insurance. Therefore, there needs to be a continuing education activity for Pharmacists and health professionals to provide information and understanding of participants with the development of drugs off the label. This activity aims to improve the competencies of the participants, as well as understand the legal prescribing rules and as input for insurance and pharmaceutical regulations. The form of activities 
that will be carried out are workshops and training. The event was held for 2 days, 14-15 October 2018 at Graha Iptekdok, FKUA. There are 10 resource persons with 11 materials divided into 6 workshops, and 1 Micromedex training activity. This activity was attended by 383 participants and 5 invitations. Among the 383 participants, 55\% were pharmacists working in hospitals, $30 \%$ were pharmacists working in pharmacies, and the rest were pharmacists working in industries, health centers, health services, and pharmacy students. Domicile participants come from various regions, with the largest percentage from Java. Based on the results of the questionnaire evaluation, the average material suitability assessment with participants' needs was 8 out of 10. On the other hand, the material mastery by the speakers was also very good (8 out of 10). While in terms of the event, the average participant rated very well (7-9 of a scale of 10). A value of 7 is given to the parameters of room facilities. Seeing the enthusiasm of the participants of the Off Label Workshop and Training in Community and Clinical Settings, the committee plans to follow up by holding a similar event to accommodate potential participants who cannot be accommodated in this event.

Keywords: Off Label Drug, Workshop, Training, Pharmacist

\section{LATAR BELAKANG}

Perkembangan ilmu kedokteran dan farmasi saat ini demikian cepat, dengan munculnya diagnosis dan obat-obat baru ataupun yang lama untuk penatalaksanaan penyakit tersebut. Dari beberapa obat yang beredar, ada yang sudah di approved oleh FDA (Food Drug Administration) atau Badan POM RI untuk indikasi penyakit tertentu, namun juga ada yang belum di approved oleh FDA maupun Badan POM untuk indikasi tertentu dari penyakit.

Obat-obat yang belum di approved tetapi tetap diresepkan oleh dokter dikenal dengan obat off Label. Salah satu contoh adalah misoprostol yang merupakan obat untuk sitoprotektif penyakit tukak lambung tetapi digunakan untuk membantu persalinan, Doksisiklin merupakan antibiotika yang digunakan untuk malaria, Levofloxacin antibiotika digunakan untuk TBC, Levamisol merupakan obat cacing yang digunakan untuk immun omodulator dan masih banyak contoh lainnya. Informasi obat off label belum banyak diketahui dan dipahami oleh para tenaga kesehatan, baik dokter maupun apoteker. Peresepan obat off label juga akan berdampak pada aturan etik dan biaya obat, apakah legal dan bisakah ditanggung oleh asuransi.

Oleh sebab itu perlu kiranya diadakan Workshop dan Pelatihan kepada para Apoteker dan profesi kesehatan untuk memberikan informasi dan pemahaman peserta dengan perkembangan obat off label ter update khususnya di rumah sakit, dan praktek komunitas (apotek, puskesmas, klinik) sehingga dapat meningkatkan kompetensi para peserta, juga memahami aturan peresepan yang legal dan sebagai masukan untuk asuransi serta peraturan farmasi. Dalam rangka Dies Natalis Universitas Airlangga dan Fakultas Farmasi Universitas Airlangga akan diadakan Workshop Obat Off Label dalam Aplikasi Klinik yang akan membahas penggunaan di bidang pediatri, kardiologi, nefrologi, onkologi, kebidanan, neurologi, dan dermatologi.

\section{METODE}

Bentuk kegiatan yang akan dilakukan adalah workshop dan training kepada apoteker, dokter, mahasiswa S1 Farmasi, Apoteker, maupun mahasiswa S2/S3 Farmasi. Materi disajikan dalam bentuk power point yang dicetak dan dijilid dengan baik dan didiskusikan di tiap sesi. Untuk diskusi kasus dalam pelatihan disiapkan tutor dari staf dosen Departemen Farmasi Klinik Fakultas Farmasi Unair untuk membantu lancarnya diskusi pelatihan. Di akhir sesi, diadakan pelatihan penggunaan software Micromedex ${ }^{\circledR}$ yang didalamnya terdapat tools untuk membantu mengidentifikasi obat-obat off label.

\section{HASIL DAN PEMBAHASAN}

\section{Off Label Drug Workshop and Training in Community Clinical Settings}

Telah dilaksanakan pada tanggal 14-15 Oktober 2017 dan berlangsung mulai jam 07.00 - 17.00, diikuti oleh 383 peserta dan 5 undangan. Di antara 383 peserta, 55\% merupakan apoteker yang bekerja di rumah sakit, $30 \%$ adalah apoteker yang bekerja di apotek, dan sisanya adalah apoteker yang bekerja di industri, puskesmas, dinas kesehatan, dan mahasiswa farmasi. Jika dilihat dari domisili asal peserta, sebaran domisili sangat bervariasi. Sebagian besar peserta berdomisili di Jawa, sedangkan sebagian kecil peserta ada yang berasal dari Provinsi Aceh, Sumatra Barat, Riau, Lampung, Kalimantan Tengah, Kalimantan Selatan, Bali, Maluku, dan Papua.

Besarnya animo calon peserta pada saat registrasi diperkirakan karena materi off label drugs ini jarang diseminarkan. Selain itu, manfaat dari pengetahuan mengenai off label drugs ini sangat besar. Apoteker yang bekerja di Apotek (community) dan Rumah Sakit (clinic) 
sering berhadapan dengan penggunaan off label drugs, sehingga update informasi off label drugs menjadi sebuah kebutuhan. Apoteker yang tidak melakukan pembaruan informasi mengenai off label drugs akan mengalami kesulitan saat berkomunikasi mengenai terapi, terutama dengan sejawat klinisi.

Materi yang disampaikan pada acara ini hanya memuat penggunaan off label drugs pada kasus-kasus mayor, yakni pada bidang jantung, ilmu penyakit dalam, ilmu kesehatan anak, obsgyn, dan onkologi. Pemilihan bidang ini disesuaikan dengan variasi penyakit yang memang memiliki prevalensi besar terjadi di masyarakat. Meskipun juga ada materi aplikasi off label drugs pada kasus minor seperti pada bidang mata dan dermatologi. Hal ini dikarenakan penggunaan off label drugs cukup banyak pada bidang tersebut. Berdasarkan hal ini, maka dipilihlah aplikasi off label drugs pada bidang-bidang tersebut. Berdasarkan hasil evaluasi kuesioner, rata-rata penilaian kesesuaian materi dengan kebutuhan peserta adalah 8 dari skala 10 (Tabel 1). Hal ini berarti bahwa lingkup materi yang diberikan sangat selaras dengan kebutuhan apoteker terkait update informasi off label drugs.

Keseluruhan materi yang disampaikan pada saat acara disajikan dalam bentuk cetak power point agar dapat disebarluaskan kepada rekan sejawat apoteker yang lain. Hal ini dilakukan dengan tujuan untuk diseminasi informasi yang nantinya diharapkan dapat mengangkat positioning apoteker dalam tim kesehatan. Selain itu, materi juga disampaikan oleh narasumber dalam workshop melalui contoh soal. Peserta dapat langsung mengaplikasikan informasi dan pengetahuan yang didapat dalam sebuah kasus dan mendiskusikan secara langsung dengan narasumber terkait. Dalam acara workshop, ada pendampingan dari fasilitator yang akan membantu peserta yang mengalami kesulitan dalam memecahkan contoh kasus.

Narasumber yang dihadirkan dalam acara ini adalah staf pengajar sekaligus praktisi, sehingga memiliki pengalaman yang banyak terkait penggunaan off label drugs dibidangnya. Hal ini juga ditunjuk- kan dari hasil evaluasi kuesioner,

Tabel 1. Penilaian pelaksanaan workshop dan training obat off label

\begin{tabular}{lc}
\hline Parameter & Nilai \\
\hline Kelancaran Acara & 9 \\
Ketepatan Waktu tiap sesi & 8 \\
Kesesuaian materi dengan kebutuhan peserta & 8 \\
Penguasaan materi oleh Narasumber & 8 \\
Makan siang \& coffee break & 8 \\
Fasilitas Ruangan & 7 \\
Kesigapan panitia dalam melayani peserta & 8 \\
\hline
\end{tabular}

dimana peserta menilai bahwa penguasaan materi oleh narasumber sangat baik ( 8 dari skala 10$)$.

Peserta rata rata sangat merasa puas mengikuti acara tersebut mulai pagi sampai sore, karena acara ini merupakan acara dengan topik yang jarang dilakukan oleh perguruan tinggi lain. Dari segi acara, rata- rata peserta menilai sangat baik (7-9 dari skala 10). Nilai 7 diberikan pada parameter fasilitas ruangan.

Di sesi terakhir, peserta mendapatkan training dari Micromedex ${ }^{\circledR}$ untuk melakukan penelusuran off label drugs. Micromedex ${ }^{\circledR}$ dipilih karena satu-satunya platform yang menyediakan informasi mengenai off label drugs. Sehingga bagi apoteker yang menghadapi kasus-kasus penggunaan obat yang belum diketahui indikasinya, dapat langsung melakukan penelusuran untuk mendapatkan indikasi off label-nya. Dalam acara training tersebut, Micromedex ${ }^{\circledR}$ juga menyediakan akun gratis yang dapat diakses peserta selama 1 hari, sehingga peserta dapat langsung berlatih untuk melakukan penelusuran.

Peserta yang mengikut Workshop and Training Off Label Drugs juga mendapatkan penghargaan berupa SKP dari PD IAI sebesar 14 SKP. Penghargaan ini nantinya akan dapat digunakan oleh apoteker untuk mengajukan perpanjangan sertifikat kompetensi apoteker. Sedangkan untuk profesi kesehatan lain yang ikut dalam acara ini, penghargaan dari PD IAI dapat disetarakan melalui ekivalensi dari ikatan profesinya masing-masing.

\section{KESIMPULAN}

Materi off label drugs dalam aplikasi klinik yang disampaikan kepada peserta sangat sesuai dengan kebutuhan mitra, yakni apoteker yang sebagian besar bekerja di rumah sakit dan klinis, didukung juga oleh narasumber yang ahli dibidannya. Penyelenggaraan acara berjalan sangat lancar dan mendapat respons yang sangat baik dari peserta, terutama dalam hal kelancaran acara, ketepatan waktu, konsumsi, fasilitas, dan kesigapan panitia.

\section{PUSTAKA}

Ahmed EL-Arabey ,Amr, New insight for metformin against bladder cancer, EL-Arabey Genes and Environment,2017, 39(13): 1-8.

Levêque ,Dominique, Off-label use of targeted therapies in oncology, World J Clin Oncol ,2016, 7(2): 253-257.

Macdonald ,John S. , Adjuvant Therapy for Colon Cancer, CA Cancer J.C 1 i n .,1997,47: 243-256. 
Moertel, Charles, R.Fleming, Thomas, Macdonald, John S, et.al., Levamizole and fluorouracil for adjuvant therapy for colon carcinoma,NEJM, 1990, 322 (6): 1-7

Pantziarka ,Pan, Bouche ,Gauthier, Meheus ,Lydie et.al., Repurposing drugs in oncology (ReDO) - cimetidine as an anti-cancer agent, ecancer 2014, 8(485):1-12.

Ibrahim, Thowfique K, AA Abdul Haium, S Chandran, and VS Rajadurai. 2014. Current Controversies in the Management of Patent Ductus Arteriosus in Preterm Infants. Indian Pediatrics Vol. 51 No. 4, p. 289-294.

Fimbres, Angela M., and Stanford T. Shulman. 2008. Kawasaki Disease. Pediatrics in Review Vol. 29 No. 9, p. 308-316.

Freeman, Alexandra F., and Stanford T. Shulman. 2006. Kawasaki Disease: Summary of the American Heart Association Guidelines. Am. Fam. Physician Vol. 74, p. 1141-1150.

Almaani, S., Meara, A., Rovin, B.H. 2016. Update on Lupus Nephritis. Clinical Journal of the American Society of Nephrology, hal. 1-11.

Borgia, R.E., Bargman, J.M., Silverman, E.D. 2016. Pediatric Lupus Nephritis. Pediatric Rheumatology, Vol.26, hal.345-362.

Mir, A.N., Geer, M.I. 2016. Off-Label Use of Medicines in Children. International Journal of Pharmaceutical Sciences and Research, Vol. 7, No.5, pp. 1820-1828.
Kimland, E., Odlind, V. 2012. Off-Label Drug Use in Pediatric Patients. Clinical Pharmacology and Therapeutics, Vol. 9, No.5., pp. 796-801.

Adamkin, D.H. and Committee on Fetus and Newborn. 2011. Clinical Report- Postnatal Glucose Homeostasis in Late-Preterm and Term Infants. Pediatrics Vol.127 No.3: 575-579.

Aynsley-Green, A., Hussain, K., Hall, J., Saudubray, J.M., Nihoul-Fekete, C., De Lonlay-Debeney, P., Brunelle, F., Otonkoski, T., Thornton, P., and Lindley, K.J. 2000. Practical management of hyperinsulinism in infancy. Arch Dis Child Fetal Neonatal Ed 2000; 82: 98-107.

Bas, F., Darendeliler F, Demirkol D, Bundak R, Saka N and Günöz H 1999. Successful Therapy with Calcium Channel Blocker (Nifedipine) in Persistent Neonatal Hyperinsulinemic Hypoglycemia of Infancy. Journal of Pediatric Endocrinology and Metabolism. Vol. 12 pp : 873-878.

Buck, M.L. 2004. Octreotide for the Management of Chylothorax in Infants and Children. Pediatric Pharmacotherapy Vol.10 No.10.

Darendeliler, F., Fournet, J-C., Bas, F., Junien, C., Gross, M-S., Bundak, R., Saka, N., Gunoz, H. 2002. ABCC8 (SUR1) and KCNJ11 (KIR6.2) Mutations in Persistent Hyperinsulinemic Hypoglycemia of Infancy and Evaluation of Different Therapeutic Measures. Journal of Pediatric Endocrinology \& Metabolism Vol. 15 pp: 993-1000. 